\title{
Hydrops fetalis
}

INSERM

\section{Source}

INSERM. (1999). Orphanet: an online rare disease and orphan drug data base. Hydrops fetalis. ORPHA:1041

Hydrops fetalis is a severe and challenging fetal condition usually defined as the excessive accumulation of fetal fluid within the fetal extravascular compartments and body cavities that manifests as edema, pleural and pericardial effusion and ascites. It is the end-stage of a wide variety of disorders. The cause may be immunologic (immune hydrops fetalis, IHF) or non immunologic (non-immune hydrops fetalis, NIHF), depending on the presence or absence of maternal antibodies against fetal red cell antigens (ABO incompatibility or rhesus (Rh) incompatibility). 